\title{
The Effect of Compensation and Work Environment Against Teacher Work Productivity
}

\author{
Rosidah $^{1 *}$, Nila Kesumawati ${ }^{2}$, Edi Harapan ${ }^{2}$ \\ ${ }^{1}$ SMP Negeri 1 Suak Tapeh \\ ${ }^{2}$ Universitas PGRI Palembang \\ *Corresponding author. Email: rosida.rahman2014@gmail.com
}

\begin{abstract}
The objectives of this study were to find out the effect of compensation and work environment on work productivity of yunior high school teachers of Suak Tapeh. The research method used is a quantitative method. Data in this study were collected through distributing the questionnaires to respondents. The results of filling out the questionnaire were analyzed using simple linear regression analysis and multiple linear regression. Population in this study were all the techers in Yunior High Schools of Suak Tapeh, amounting to 83 teachers. Because the population in this study is below 100 people, so this study is called a population study. All population numbers were used as research samples as many as 83 teachers. The results showed that: (1) there is a significant influence between compensation on teacher's work productivity; (2) there is a significant influence between the work environment on teacher's work productivity; (3) there is a significant influence between compensation and the work environment on teacher's work productivity.
\end{abstract}

Keywords: Compensation, Work Environment, Work Productivity

\section{INTRODUCTION}

Education is a conscious effort that is deliberately designed to achieve predetermined goals and contains personality development. According to [1] "Education aims to help young people develop all the elements of their personal potential, both spirituality, morality, sense of sociality, and rationality". Besides that, education also aims to improve the quality of human resources, one of which can be seen from the quality of these educational institutions.

Teacher work productivity can be viewed from the teacher's duties contained in the main tasks and functions of the teacher. Types of teacher duties as listed in Government Regulation (PP) Number 19 of 2017 concerning Amendments to Government Regulation Number 74 of 2008 concerning Teacher Article 1, Teachers are professional teachers with the main task of educating, teaching, guiding, directing, training, assessing, and evaluating students in early childhood education through formal education, basic education, and secondary education.

Compensation received by teachers, especially teachers with the status of the State Civil Apparatus (ASN) in the form of basic salary, child and wife allowances, pension allowances, certification allowances, excess teaching allowances, and foundation allowances (if the teacher teaches in private schools). All these allowances have been budgeted for in the APBD and APBN. The amount of compensation received by teachers is demanded to further increase their productivity in schools. However, there are also teachers who are given additional assignments (for example, to become committee members of school activities) but do not want to carry out these tasks on the grounds that there is no additional honorarium. There are also teachers who are not diligent in completing work, for example in completing annual programs, resulting in delays in carrying out work. This is not in accordance with the time set in one fiscal year. And in the implementation of learning there are still teachers who do not use various learning methods. Sometimes the media used cannot stimulate students' interest in learning such as attractive props so that students are less interested in learning.

Apart from compensation, the factor that also affects teacher work productivity is the work environment. According to [2] to create a conducive work environment, at least two things are needed, namely the teacher himself and a good relationship between the teacher and parents and the surrounding community. In line with this opinion, supportive working conditions are needed, namely a comfortable working environment for them. A good work environment will facilitate them to work better too. If the work environment in school is pleasant, it will stimulate teachers to have the responsibility of carrying out their duties and obligations properly and 
happily [3]. It is true that some teachers argued with each other, but the principal had nurtured them and reconciled them. A work environment condition can be said to be good if the work environment is healthy, comfortable, safe and pleasant for employees in completing their work and there is no hostility between co-workers. According to [4]. that "The work environment is designed in such a way as to create a work relationship that binds work with the environment. A pleasant work environment can make employees feel at home in completing their work and are able to achieve optimal results. Conversely, if the working environment conditions are not adequate, it will cause a negative impact in reducing the productivity level of employee performance.

Apart from the problem of compensation and the work environment, it turns out that there are other factors that cause a decrease in teacher work productivity, that factor is work discipline, from the attendance data for the last three months in 2019 there was a delay of around $7 \%-8 \%$ teachers, in addition to discipline, workload problems also caused decrease in work productivity, teachers feel the existing workload is too large compared to the incentives received.

Several factors caused the decline in productivity. Then the authors conducted a pre-survey with 15 teachers at SMP Negeri 1 Suak Tapeh. The purpose of conducting the pre-survey was to identify the two biggest factors that caused the decline in teacher work productivity. From the pre-survey results, it is known that 2 main factors need to be considered, namely the compensation factor and the work environment, which can be seen in the table below.

Table 1. Factors That Should Get More Attention From Schools

To Increase Teacher Work Productivity

\begin{tabular}{|c|l|c|c|}
\hline No & Influenced factors & $\begin{array}{c}\text { total } \\
\text { Answers }\end{array}$ & Percentage\% \\
\hline \hline 1 & Work Environment & 11 & 36.6 \\
\hline 2 & Discipline & 4 & 13.4 \\
\hline 3 & Workload & 6 & 20 \\
\hline 4 & Compensation & 9 & 30 \\
\hline
\end{tabular}

Source: Observations with 15 teachers of SMPN 1 Suak Tapeh

The data in the table states the results of observations made to 15 teachers at SMP Negeri 1 Suak Tapeh. Each teacher who is a respondent is allowed to answer 2 factors that affect teacher work productivity. Based on the data above, it is known that the work productivity of SMP Negeri 1 Suak Tapeh teachers has decreased and is less than optimal due to 2 factors, namely the Work Environment and Compensation. From the results of the pre-survey, it can be seen that the two highest factors are Compensation and the Work Environment, each at $30 \%$ and $36.6 \%$. The smallest factor that supports teacher work productivity is the workload of $20 \%$.

With the background of the problems in the school that the author studied. So the authors will examine "The effect of compensation and the work environment on the productivity of the work of teachers in all SMP Negeri Suak Tapeh District."

\section{METHODS}

According to [5]., the research method is a scientific way to obtain data with specific purposes and uses. In line with [6]. the research method is a scientific way to obtain data for specific purposes. The approach used in this research is the quantitative approach.

Because the total population is not greater than 100 respondents, the authors take $100 \%$ of the total population at the State Junior High School in Suak Tapeh District as many as 83 respondents. The technique of collecting data through a questionnaire / questionnaire. Before the questionnaire / questionnaire is distributed to the respondents, the validity and reliability are tested first.

The data analysis technique in this study used inferential statistics, namely simple linear regression test and multiple linear regression test with the help of the SPSS For Windows Version 21 program. The level of criteria for testing this hypothesis with a confidence level of $95 \%(\alpha=0.05)$. significance level $>\alpha(5 \%$ or $0.05)$, then Ho is accepted, meaning $\mathrm{Ha}$ is rejected, but if the significance level is $\leq \alpha(5 \%$ or 0.05$)$ then Ho is rejected, meaning $\mathrm{Ha}$ is accepted. Before carrying out the test, the prerequisite analysis was carried out first. This prerequisite test is needed to find out whether data analysis for hypothesis testing can be continued or not (Kesumawati and Aridanu, 2018: 67). Following are the prerequisite tests used: (1) normality test, (2) linearity test, and (3) multicollinearity test.

\section{RESULTS AND DISCUSSION}

\subsection{Effect of Compensation on Teacher Work Productivity}

Research conducted at State Junior High Schools in Suak Tapeh District obtained a hypothesis that compensation has an effect on teacher work productivity. Based on the results of hypothesis testing, it is obtained that the value of the significant level (sig) of the compensation variable (X1) is 0.000 less than 0.05, thus Ho is rejected and $\mathrm{Ha}$ is accepted. This means that it can be said that the compensation variable (X1) has a significant effect on the teacher 
work productivity variable (Y) in State Junior High Schools in Suak Tapeh District.

Teacher work productivity is the ratio of the work output to the time it takes to produce a product from a teacher. The realization of superior and outstanding schools cannot be separated from the effective work productivity of teachers who play a role in these schools. Teacher work productivity is basically focused on teacher behavior in implementing work programs to achieve these goals, while regarding teacher work productivity can be seen to what extent the teacher's work productivity can have an influence on students. Specifically, the goal of teacher work productivity also requires teachers to make specific decisions, where the learning objectives in schools are clearly stated in the form of the behavior of a teacher, then transferred to their students. There are several factors causing the decline in teacher work productivity, including compensation, work environment and work motivation.

Based on preliminary observations made on teachers at SMP Negeri 1 Suak Tapeh in the Banyuasin Regency area, it can be seen that all teachers who have additional assignments receive compensation as an effort to motivate them to be more active and enthusiastic at work. This is reinforced by the calculation of the significant level obtained on the compensation variable on teacher work productivity which is smaller than the alpha value $(\alpha)$, so that the results show that there is a positive influence between the two variables. The results of this study are in line with the opinion of [7].which states that compensation is everything that employees receive as remuneration for their work. According to [8].compensation is anything that employees receive in return for their work. Compensation is a way for the personnel department to improve work performance, motivation and employee job satisfaction through compensation. According to [9].compensation is intended as a company reward for the sacrifice of time, energy and thoughts that they have given to the company. [10].argues that compensation can be defined as any form of award given to employees as remuneration for the contributions they provide to the organization. While the definition of compensation according to William B. Wearther and Keith Davis [11].compensation is what employees receive in exchange of their work. Whether hourly wages or periodic salaries, the personnel department usually designs and administers employee compensation This research is in line with the research conducted by [12].which shows that compensation has a significant and positive effect on the performance of the Batusangkar 3 Middle School teachers. This study is similar to research by [13].which states that there is a strong relationship between the compensation variable and the performance of high school teachers in Bangkinang District.

An effective compensation system is an important part of human resource management because it helps attract and maintain teacher morale, interest and motivation. In addition, the compensation system also has an impact on teacher work productivity. Compensation systems can include salaries, bonuses and incentives. And also in the form of insurance, benefits and pension funds.

\subsection{Effect of Work Environment on Teacher Work Productivity}

Based on the results of hypothesis testing, the significant level ( $\mathrm{sig}$ ) of the work environment variable $\left(X_{2}\right)$ is 0.000 smaller than the value $(\alpha) 0.05$, thus Ho is rejected, meaning that $\mathrm{Ha}$ is accepted. So it can be concluded that the work environment variable $\left(\mathrm{X}_{2}\right)$ has a significant effect on teacher work productivity (Y) at State Junior High Schools in Suak Tapeh District. This means that the work environment in State Junior High Schools in Suak Tapeh District in the form of togetherness, intimacy and kinship that is created both among colleagues and with superiors is the spirit in increasing the work productivity of all teachers at the school.

Understanding the work environment according to [14].is "Everything that is around the workers that can affect him in carrying out the tasks assigned". Meanwhile, [15] states that "the work environment can be interpreted as a whole tooling tool faced by the surrounding environment where a person works, the work method, as the influence of his work both as an individual and as a group". Another opinion was put forward by [16] "The work environment is a condition that is related to the characteristics of the place where the work is carried out on the behavior and attitudes given by workers where it is related to the process of various psychological changes occurring in it is caused by things that are experienced in their work or in certain conditions that need more attention by the organization which can cause boredom at work, work that is always monotonous and work exhaustion.

Based on the above definition, it can be concluded that the work environment is an environment in which there is a whole formation of behavior related to working conditions so that it can affect him in carrying out his duties in his job.

Based on the results of data processing in the linearity test above, it is known that the significant value obtained is 0.236 . This means that the significance value is greater than the error level $(0.236>0.05)$, so it can be concluded that between the 
work environment variable (X2) and the Teacher Work Productivity (Y) there is a linear relationship. This means that the more conducive the work environment is, the more the teacher's work productivity will increase, and vice versa, the less conducive the work environment is, the lower the teacher's work productivity.

The results of a similar research conducted by [17] show that there is a positive and significant effect of the quality of the school environment on the work productivity of high school teachers in Bangkinang district. Likewise, research conducted by [18] shows that there is a positive and significant influence of the work environment on the performance of high school teachers in Muara Padang district.

Thus it can be concluded that the work environment is a measuring tool that will affect teacher productivity if the work environment in the school environment is good. A pleasant work environment for teachers through tying harmonious relationships with superiors, colleagues, and subordinates has a positive impact on teachers so that teacher work productivity can increase.

\subsection{Effect of Compensation and Work Environment on Teacher Work Productivity}

Based on the results of testing the multiple linear regression hypothesis between the compensation variable $(\mathrm{X} 1)$ and the work environment (X2) on teacher work productivity $(\mathrm{Y})$, the regression equation constant value $\alpha$ is 16.003 and the coefficient value of the independent variable b1 is 0.505 and b2 is 0.640 , so that the equation is obtained. regression namely:

$\mathrm{Y}=\mathrm{a}+\mathrm{b} 1 \mathrm{X} 1+\mathrm{b} 2 \mathrm{X} 2$ and $\mathrm{Y}=16.003+0.505 \mathrm{X} 1$ $+0.640 \mathrm{X} 2$ This means that compensation and the work environment have significantly increased teacher work productivity.

Productivity is a mental attitude that always tries and has the view that today's life is better than yesterday and tomorrow is better than today. Productivity of work is not only intended to get as much work as possible, but the quality of work is also important. As stated, individual productivity can be assessed and what the individual does in his work. In other words, individual productivity is how a person performs his job or performance.

Compensation is often used in everyday life, including in education. The definition of compensation referred to here is all the rewards received by teachers for their work at an educational institution where the compensation is in the form of money, either directly or indirectly.

The work environment is one of the important factors that a manager needs to pay attention to in maintaining his human resources, namely by providing and striving for a work environment that is comfortable, safe and conducive because that is where an employee spends his working time every day, then with a comfortable work environment. , safe and conducive will increase high morale.

Based on this research, it can be interpreted that teacher work productivity will increase if there is compensation or rewards received by the teacher for his work. Teacher work productivity can also be optimized with a work environment that is comfortable, safe and conducive because this can increase high morale. Thus the findings of this study support the opinion that compensation and the work environment have a significant effect on teacher work productivity.

The results of this study are in line with research conducted Kristiawan [19], with the title The Effect of Compensation, Work Motivation and Discipline on Work Productivity of State Elementary School Teachers in Palembang. The data in this study were collected through distributing questionnaires to respondents. The results of filling out the questionnaire were analyzed using multiple regression analysis through the $\mathrm{t}$ test, $\mathrm{F}$ test, and determination coefficient test. The population in this study were the principals of all State Elementary Schools (SD) throughout Palembang, totaling 247 schools.

The number of samples from the population in this study is based on calculations using the Slovin formula. So, the samples used in this study were as many as 71 (seventy one) principals from all State Elementary Schools (SD) throughout Palembang. The results of this study indicate that: (1) there is a significant effect of partial compensation on teacher work productivity; (2) there is a significant influence between work motivation partially on teacher work productivity; (3) there is a partial effect of discipline on teacher work productivity; and (4) there is an effect of compensation, work motivation and discipline simultaneously on teacher work productivity [20] [21].

\section{CONCLUSION}

Based on the results of hypothesis testing, the significant level (sig) of the work environment variable $\left(\mathrm{X}_{2}\right)$ is 0.000 smaller than the value $(\alpha) 0.05$, thus Ho is rejected, meaning that $\mathrm{Ha}$ is accepted. So it can be concluded that the work environment variable $\left(\mathrm{X}_{2}\right)$ has a significant effect on teacher work productivity (Y) at State Junior High Schools in Suak Tapeh District, the authors convey that based on the results of testing the multiple linear regression hypothesis between the compensation variable (X1) and the work environment (X2) on teacher work productivity (Y) there is a significant influence 
between compensation on teacher's work productivity; (2) there is a significant influence between the work environment on teacher's work productivity; (3) there is a significant influence between compensation and the work environment on teacher's work productivity.

\section{ACKNOWLEDGMENT}

The author would like to thank all those who helped write and publish this journal so that this article can be published.

\section{REFERENCES}

[1] Alwi, S. (2008). Manajemen Sumber Daya Manusia.Edisi kedua. Yogyakarta: BPFE Yogyakarta.

[2] Mulyasa, H. E. (2013). Manajemen \& kepemimpinan Kepala Sekolah. Jakarta: Bumi Aksara.

[3] Supardi. (2013) Kinerja Guru. Jakarta: Rajawali Press.

[4] Lewa, K., Iip, Idham, Eka \& Subowo. (2005). "Pengaruh Kepemimpinan, Lingkungan Kerja Fisik dan Kompensasi Terhadap Kinerja Karyawan di PT. Pertamina (Persero) Daerah Operasi Hulu Jawa Bagian Barat Cirebon." Jurnal SINERGI: Kajian Bisnis dan Manajemen Edisi Khusus on Human Resources.

[5] Sugiyono, (2017). Metode Penelitian Kuantitatif, Kualitatif, dan R\&D. Bandung : Alfabeta, CV.

[6] Darmadi, Hamid. 2013. Metode Penelitian Pendidikan dan Sosial. Bandung: Alfabeta.

[7] Notoatmodjo, S. (2003). Pengembangan Sumber Daya Manusia. Jakarta: Rineka Cipta.

[8] Handoko, T. Hani. (2011). Manajemen Personalia dan Sumberdaya Manusia. Yogyakarta: BPFE.

[9] I. Fathurrochman, S. Danim, S. Anwar AB, N. Kurniah, and D. H. Ristianti. (2021). "Theoretical Review of the Implementation Islamic Boarding School Curriculum Management in Indonesia," Int. J. Educ. Res. Dev., vol. 1, no. 1, pp. 1-15.

[10] I. Fathurrochman, S. Danim, S. Anwar AB, and N. Kurniah. (2021). "The School Principals , Role in Education Management at the Regional Level: An Analysis of Educational Policy in the Industrial Revolution 4 . 0," Adv. Soc. Sci. Educ. Humanit. Res., no. 532, pp. 237-242.

[11] Sutrisno, E. (2016). Manajemen Sumber Daya Manusia. Jakarta: Kencana Prenada Media Grup.
[12] Panggabean, M. (2002). Manajemen Sumber Daya Manusia. Ghalia Indonesia. Jakarta

[13] Hasibuan, M. (2003). Organisasi dan Motivasi Dasar Peningkatan Produktivitas. Jakarta: Bumi Aksara

[14] Pitri, A. (2017). Pengaruh Kompensasi terhadap Kinerja Guru di SMP NEGERI 3 Batusangkar Peneliti Independen IAIN Batusangkar. JMKSP Jurnal Manajemen, Kepemimpinan, dan Supervisi Pendidikan Vol.2 No. 1, Jan-Juni 2017.

[15] Azwar, B. (2013). Kajian Pengaruh Kompensasi terhadap Kinerja Guru SLTA di Kecamatan Bangkinang. Menara, Vol. 12 No. 2 Juli - Desember 2013.

[16] Alex, S. N. (2000). Manajemen Personalia: Manajemen Sumber Daya Manusia, Ed. 3, Ghalia Indonesia, Jakarta

[17] Simanjuntak, P. (2003). Manajemen Hubungan Industrial. Jakarta: Pustaka Sinar Harapan

[18] Schultz, D., Schultz, S. E. (2006). Psychology \& Work Today Ninth Edition. New Jersey : Pearson Education. Inc

[19] Komalia, (2013). Kualitas Lingkungan Sekolah dan Motivasi Kerja terhadap produktivita Kerja Guru. Jurnal Adminisistrasi Pendidikan Vol.XVII No.1 Oktober 2013

[20] M. Marphudok, B. Lian, and H. Fitria. (2020). "Pengaruh Lingkungan Kerja dan Motivasi Kerja terhadap Kinerja Guru SMA di Kecamatan Muara Padang”, Jurnal Intelektualita: Keislaman, Sosial dan Sains, vol. 9, no. 1, pp. 167-178.

[21] Perawati. (2018). Pengaruh Kompensasi, Motivasi Kerja dan Disiplin Terhadap Produktivitas Kerja Guru, Universitas PGRI Palembang. Tesis. Program Pasca Sarjana Universitas PGRI Palembang 